\title{
Long-term Effectiveness of Occlusal Splint Therapy Compared to Placebo in Patients with Chronic Temporomandibular Disorders
}

\section{Usporedba dugotrajne učinkovitosti stabilizacijske i placebo udlage u terapiji kroničnih temporomandibularnih poremećaja}

Department of Removable Prosthodontics, School of Dental Medicine, University of Zagreb, Croatia

Zavod za mobilnu protetiku Stomatološkog fakulteta Sveučilišta u Zagrebu

\section{Abstract}

Purpose: The aim of this study was to compare long-term effectiveness of stabilization splint (SS) with that of placebo splint (PS) in chronic TMD patients and to investigate differences in treatment outcomes based on diagnostic subgroups [disc displacement (DD)/myofascial pain (MP)]. Materials and Methods: Thirty-four female participants, diagnosed with chronic TMD, were classified in groups: one provided with SS and other with PS and were followed for six months. Treatment outcomes included spontaneous pain [visual analogue scale (VAS)], self-perceived quality of life (OHIP-14), painfree maximal mouth opening (MCO), maximal mouth opening (MMO), level of perceived stress (PSS), characteristic pain intensity [graded chronic pain scale (GCPS)], and functional jaw limitation [jaw functional limitation scale (JFLS)]. Results: Baseline characteristics did not differ significantly between the two groups $(p>0.05)$. After six months of treatment the changes in spontaneous pain and OHIP-14 scores differed significantly between treatment groups ( $p=0.004, p=0.02$ respectively), with greater reduction in SS compared to the PS group. Pain-free maximal mouth opening did not change significantly over time, however MCO values differed significantly between the two treatment groups, with greater overall values in the SS compared to the PS group $(p=0.046)$, as well as between TMD subgroups, with greater overall values in MP compared to DD patients $(p=0.03)$. In the SS group, significant difference in JFLS categories was found between baseline and after 6 months of treatment in all except emotional and verbal expression (mastication $p=0.00015$; vertical jaw mobility $p=0.00018$ ). No such changes in JFLS categories were observed in the PS group. Conclusions: During 6-month period, SS was more effective than PS in reducing spontaneous pain and improving self-perceived quality of life and functional limitations of the lower jaw. Moreover, significantely higher values of pain-free mouth opening were observed in patients treated with stabilization splint. While placebo might be partly responsible for improving the symptoms of TMD, it seems that itcannot maintain a continual long-term positive therapeutic effect.
Received: May 16, 2019

Accepted: August 21, 2019

Address for correspondence Ema Vrbanović, dr.med.dent. Department of Prosthodontics School of Dental Medicine University of Zagreb Gunduliceva 5, HR-10000 Zagreb, Croatia evrbanovic@sfzg.hr

Key words

Temporomandibular Disorders; Occlusal Splint; Chronic Pain; Facial Pain

\section{Introduction}

Temporomandibular disorders (TMDs) is a term covering neuromuscular and musculoskeletal conditions that affect masticatory muscles and temporomandibular joints (TMJ) as well as surrounding structures (1). The most common TMD diagnoses are myofascial pain and disc displacement $(2,3)$. Temporomandibular disorders can affect anyone, however women aged $20-50$ years are most affected (4). The most common symptoms for which patients seek help are pain in orofacial region and limited lower jaw movements, which are often aggravated by function. In addition, patients are often worried about the sounds that appear in the TMJ (clicking or popping sounds, or crepitations) (5). The complexity of the etiopathophysiology of disorders and its effect on patients' quality of life, as it is frequently stated in various research studies, requires thorough and careful therapeutic approach (1-5).
Uvod

Temporomandibularni poremećaji (TMP) obuhvaćaju neuromuskularna i muskuloskeletna bolna stanja koja zahvaćaju žvačne mišiće te čeljusne zglobove (TMZ) i okolne strukture (1). Najčešći oblik poremećaja je tzv. miofascijalna bol, a najč̌šći intraartikularni oblik TMP-a jest pomak zglobne pločice $(2,3)$. TMP se može pojaviti u svim populacijskim skupinama, no najčešći je kod žena između 20 i 50 godina (4). U karakteristični trijas simptoma TMP-a, zbog kojih pacijenti najčešće traže pomoć, ubrajaju se orofacijalna bol, ograničenja u kretnjama donje čeljusti koja se pogoršavaju u funkciji te zvukovi u zglobu (kliktaji, pucketanja, krepitacije) (5). Kako su etiologija i patofiziologija poremećaja složene, a utjecaj na kvalitetu pacijentova života prilično velik, pristup kliničara dijagnostici i terapiji TMP-a trebao bi ponajprije biti temeljit $(1-5)$. 
Treatment of TMD can be divided into non-invasive, reversible modalities, and options that are more invasive. There is an agreement among researchers that conservative and reversible therapies provide satisfactory results in reducing pain and improving jaw function, however no specific therapy has been proven to be more effective than the other (6). Majority of patients respond well to combination of behavioral and physical therapy approaches, but the most popular modality is certainly occlusal splint (7). Various types of splints, with different indications and functions, are used. However, the stabilization splint (SS), a full-arch hard acrylic device made in the position of centric relation (CR) is most frequently used type of device (8). The success of SS is attributed to various factors including changes in condylar position, elimination of occlusal interferences, establishment of stable occlusal relationship with uniform teeth contacts, changes in neuromuscular activity, and increase in vertical dimension of occlusion which probably contributes to the relaxation of the musculature and the relief of TMJ $(7,8,9)$. It is not completely clear why any therapy is clinically more successful than no treatment at all, but researchers agree that the improvement of symptoms is probably due to combination of previously mentioned factors, and some of them consider placebo to be one of those factors too. Some studies are pointing out that SS does not appear to produce a better clinical outcome than a soft splint, a non-occluding palatal splint and physical therapy $(7,10)$, while others claim that hard stabilization appliance provides better clinical outcomes than placebo (11). The question remains whether the treatment success achieved with a SS is longer-lasting than the success attained with splint therapy that does not provide centric relation position and has a negligible influence on vertical dimension of occlusion.

The aim of this study was to compare a 6-month effectiveness of stabilization splint with that of placebo splint. The null-hypothesis was that there would be no difference between treatment groups in a 6-month treatment period.

\section{Materials and methods}

The study was approved by the Ethics Committee of the School of Dental Medicine, University of Zagreb (01-PA26-6/15, item 3.2). All participants were informed about the study protocol and provided with written informed consent. All experimental procedures were conducted in accordance with ethical standards of the Helsinki Declaration.

\section{Participants}

This randomized controlled clinical trial was carried out at the Department of Removable Prosthodontics, School of Dental Medicine, University of Zagreb from June 2016 to June 2019. The participants were recruited from patients seeking treatment for chronic TMD pain and/or limited lower jaw movements. In the research period, the only patients who met the inclusion criteria were women, therefore exclusively female participants were included in the study. The inclusion criteria were as follows: the report of chronic pain, lasting more than 6 months, spontaneous pain $>30 \mathrm{~mm}$ on visual analogue scale (VAS), and diagnosis of myofascial pain (MP) or disc displace-
U liječenju TMP-a preferiraju se neinvazivni, reverzibilni terapijski postupci kojima je svrha poboljšati cjelokupnu funkciju žvačnog sustava. Ipak, u studijama u kojima su se promatrale razlike u liječenju uglavnom se ne upućuje na prednost pojedine neinvazivne terapijske opcije u usporedbi $s$ drugom, pa zato ne možemo sa sigurnošću tvrditi koja od njih ima prioritet u liječenju TMP-a (6).

Velikom broju pacijenata najbolje odgovara kombinacija bihevioralne i fizikalne terapije, a u kliničkome radu najčešce se preporučuje popularna okluzijska udlaga (7). U literaturi se spominju razne udlage čiji oblik uglavnom ovisi o indikaciji, no široko je prihvaćena i uspješna u liječenju stabilizacijska udlaga (SU) izrađena od tvrdog akrilata tako da omogućuje doticaje u centričnoj relaciji (CR-u) (8). Terapijski učinak SU-a pripisuje se različitim čimbenicima, pa se tako smatra da on mijenja položaj kondila u zglobnoj jamici, uklanja okluzijske interferencije, održava stabilne okluzijske odnose i jednakomjerne kontakte, smanjuje neuromuskularnu aktivnost i podiže vertikalnu dimenziju okluzije, što vjerojatno pridonosi opuštanju muskulature i rasterećenju TMZ-a (7, 9). Ipak, još nije sasvim jasno kako i zašto se stabilizacijskom udlagom postiže olakšanje simptoma TMP-a. Znanstvenici se uglavnom slažu da je učinak vjerojatno posljedica kombinacije spomenutih čimbenika, ali i placebo učinka. Istraživanja o placebo učinku udlage nude proturječne zaključke. Naime, dio znanstvenika ističe kako ne postoji razlika između terapijskih ishoda između SU-a, neokludirajuće nepčane ploče i fizikalne terapije $(7,10)$, a drugi da se tvrdom stabilizacijskom udlagom postižu bolji rezultati u liječenju negoli pri primjeni placebo udlage $(11,12)$. Nameće se pitanje je li terapijski učinak postignut SU-om dugotrajniji od terapijskog učinka naprave čiji oblik ne omogućuje uspostavljanje međučeljusnih odnosa u CR-u i ima zanemariv učinak na vertikalnu dimenziju okluzije.

Cilj ove studije bio je usporediti šestomjesečnu učinkovitost stabilizacijske udlage rezultate s onima postignutima placebo udlagom. Nulta hipoteza bila je da neće biti razlika između tih terapijskih skupina tijekom šest mjeseci.

\section{Materijali i metode}

Studiju je odobrio Etički odbor Stomatološkog fakulteta Sveučilišta u Zagrebu (01-PA-26-6/15, item 3.2). Svi ispitanici bili su informirani o njezinu protokolu i dali su svoj pristanak. Eksperimentalni postupci primjenjivani u studiji ni na koji način nisu u sukobu s etičkim načelima Helsinške deklaracije.

\section{Sudionici}

Kontrolirano randomizirano kliničko istraživanje provedeno je u Zavodu za mobilnu protetiku Stomatološkog fakulteta u Zagrebu od lipnja 2016. godine do lipnja 2019.

Tijekom trajanja studije jedino su žene zadovoljile kriterije za uključivanje u istraživanje pa su zato samo one uvrštene u istraživačku skupinu. Kriteriji za sudjelovanje bili su: kronična bol koja traje dulje od šest mjeseci, spontana bol veća od $30 \mathrm{~mm}$ prema procjeni na vizualno-analognoj ljestvici (VAS-u) te dijagnoza bolnog miofascijalnog poremećaja ili pomaka zglobne pločice. Kriteriji za isključivanje bili su: ostala orofacijalna bolna stanja nevezana za TMP, degene- 
ment (DD). Exclusion criteria were orofacial pain not related to TMD, degenerative joint disease, oral lesions, periodontal disease, systemic diseases, pregnancy, as well as previous active treatment for painful TMD. Patients with combined MP and DD were not considered for the study.

\section{Sample size estimation}

A statistical power analysis was performed for sample size estimation based on data from Michelotti et al. (12). The minimum difference in VAS and maximal comfortable mouth opening (MCO) scores between treatment groups was estimated to be $8.8 \mathrm{~mm}$ and $3.4 \mathrm{~mm}$, respectively, with the standard deviation of $7.5 \mathrm{~mm}$ and $2.5 \mathrm{~mm}$, respectively. With an alpha $=.05$ and power set at $80 \%$, the projected sample size was approximately $\mathrm{N}=26$ (13 per group).

\section{Study protocol}

Out of 38 female patients that met the inclusion criteria, 2 of them declined to participate in the study due to travel complications, thus 36 participants were included in the study. The randomization was performed using Microsoft Excel software after the codification of each patient. Two of the participants dropped out before they were provided with a splint. Eventually, 34 patients were randomized in SS group, and placebo splint (PS) group. The number of subjects was 19 in the SS group, and 15 in the PS group. Two of the patients in each treatment group withdrew before the completion of the therapy, thus 17 patients in the SS group and 13 patients in the PS group completed the 6-month treatment (Figure 1).

At the baseline (T0) all patients were evaluated by the expert in TMD (IA). The patients were diagnosed using Diagnostic criteria for temporomandibular disorders (DC/TMD) (13). After the patients had been provided with a splint, they were followed during a 6-month period with follow-up appointments at 1st (T1), 3rd (T2) and 6th (T3) month. The rativni poremećaji TMZ-a, pacijenti već liječeni od bolnoga TMP-a, trudnoća, parodontna bolest, oralne lezije te kronične sistemske bolesti. $U$ istraživanje također nisu bili uključeni pacijenti s kombinacijom miofascijalnog bolnog poremećaja i pomaka zglobne pločice.

\section{Procjena potrebne veličine testiranog uzorka}

Za procjenu veličine uzorka obavljena je analiza snage statističkog testa prema podatcima istraživanja Michelotti i suradnika (12). Minimalne razlike u iznosu VAS-a bile su 8,8 $\mathrm{mm}$ sa standardnom devijacijom koja je iznosila $7,5 \mathrm{~mm}$, a maksimalnog bezbolnog otvaranja (MCO-a) 3,4 mm sa standardnom devijacijom koja je iznosila $2,5 \mathrm{~mm}$. $S$ alfa $=0,05 \mathrm{i}$ snagom testa na $80 \%$, predviđena veličina uzorka bila je $\mathrm{N}=$ 26 (s 13 ispitanika u skupini).

\section{Protokol istraživanja}

Od 38 pacijentica koje su zadovoljile sve kriterije, dvije su odbile sudjelovati u studiji zbog poteškoća s prijevozom. Od preostalih 36 pacijentica uključenih u studiju, dvije su odustale prije nego što im se izradila udlaga. Naposljetku, u aktivnu i placebo skupinu slučajnim odabirom raspoređene su 34 pacijentice - 19 u skupinu sa SU-om i 15 u skupinu s PUom. Po dvije pacijentice povukle su se prije završetka terapije, tako da je šestomjesečno praćenje završilo 17 pacijentica u skupini sa SU-om i 13 u skupini s PU-om (slika 1.). Nakon što su pacijenticama priključeni kodovi, napravljena je randomizacija s pomoću softvera Microsoft Excela.

Početni pregled i procjenu (T0) obavio je stručnjak iz područja TMP-a (I. A.). Dijagnostika je provedena s pomoću dijagnostičkog kriterija za temporomandibularne poremećaje (DC/TMD-om) (13). Pacijenticama je dodijeljeno terapijsko sredstvo nakon čega su praćene šest mjeseci s kontrolnim pregledima i procjenom nakon prvoga ( $\mathrm{T}$ 1), trećeg ( $\mathrm{T}$ 2) i šestog mjeseca (T 3). Kliničarka koja nije znala početnu dijagnozu, početni intenzitet boli i vrstu terapije, obavljala

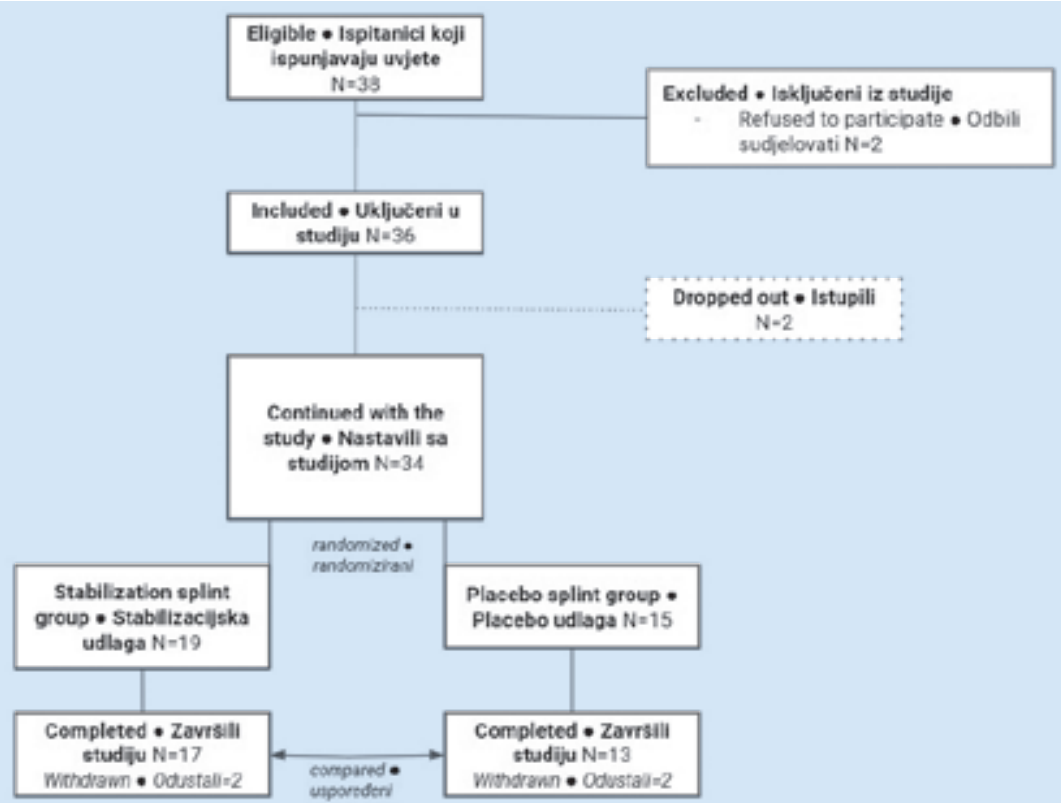

Figure 1 Flowchart illustrating the selection and distribution of the participants into the study groups Slika 1. Dijagram koji prikazuje izbor i distribuciju ispitanika 
follow-up evaluations (T1, T2, T3) were carried out by a clinician (EV) blinded for the type of treatment, the initial diagnosis and the pain intensity.

\section{Treatment procedure}

Both treatment groups were equally informed and counseled about their condition prior to splint therapy, in terms of explanation of the origin and prognosis of the disease.

The maxillary stabilization splint was fabricated on stone cast in ARTEX articulator. It was a hard acrylic splint (Resilit-S, Erkodent, Siemensstraße 3, 72285 Pfalzgrafenweiler, Germany), with a $2 \mathrm{~mm}$ thickness at the level of the first molar. The clinician (IA) adjusted the splint so that that the opposing teeth occluded uniformly and simultaneously with the occluding surface of the splint in centric relation. The same clinician adjusted the splint at follow-up appointments if it was needed.

The placebo splint was made of a thin thermoforming foil (Erkodent, $0.5 \mathrm{~mm}$ ) fabricated on the patient's maxillary stone cast. All contacts that interfered with maximal intercuspation have been removed. The increase in vertical dimension was less than $0.5 \mathrm{~mm}$, thus providing negligible influence on occlusion and condylar position. (Figure 2 and 3).

The same dental technician made all splints. Patients in both treatment groups were instructed to wear their splints only during sleep. je kontrolne preglede i kontrolne procjene terapijskih ishoda (T 1, T 2, T 3).

\section{Postupak liječenja}

Prije nego što su pacijentice u objema terapijskim skupinama počele s terapijom, informirane su i savjetovane o nastanku TMP-a te o njegovim simptomima i prognozi.

Tvrda akrilatna stabilizacijska udlaga bila je napravljena na gipsanom modelu gornje čeljusti u artikulatoru ARTEX (Resilit-S, Erkodent, Siemensstraße 3, 72285 Pfalzgrafenweiler, Njemačka). Udlaga za pacijente u placebo skupini napravljena je od tanke termoobradive folije (Erkodent $0,5 \mathrm{~mm}$ ). Folija je bila zagrijana i otisnuta na gipsani model gornje čeljusti. Rezultat je bio vrlo tanak film koji je slijedio okluzijske površine zuba. Uklonjeni su svi kontakti koji su ometali ostvarivanje simultanih doticaja u maksimalnoj interkuspidaciji. Vertikalna dimenzija okluzije povećala se za manje od $0,5 \mathrm{~mm}$, zbog čega je utjecaj na okluziju i položaj kondila vjerojatno bio zanemariv (slike 2. i 3.). Sve udlage izradio je isti dentalni tehničar, a okluzijski ih je uskladila kliničarka (I. A.). Ista kliničarka prilagođavala ih je i na kontrolnim pregledima. Pacijentice u objema terapijskim skupinama dobile su upute da udlage nose samo dok spavaju.
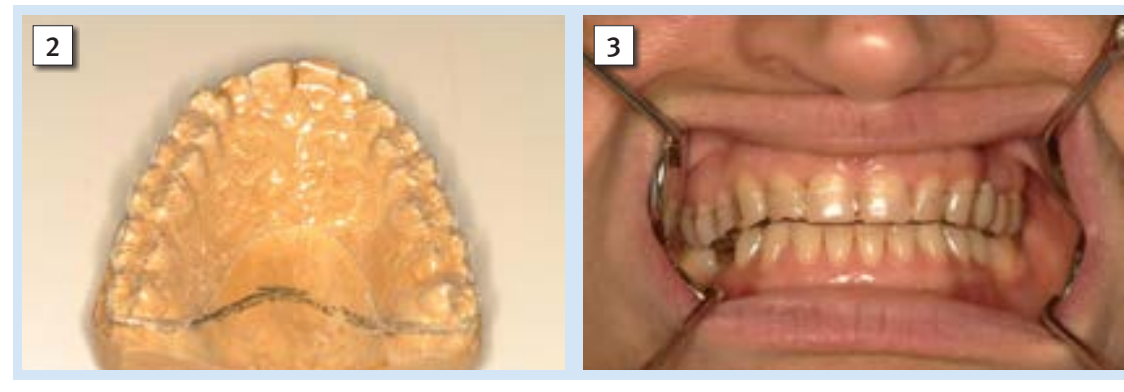

Figure 2 The specific design of the placebo splint adjusted to the upper stone cast

Slika 2. Specifičan dizajn placebo udlage prilagođen na gipsani model gornje čeljusti

Figure 3 Placebo splint in the mouth of the patient

Slika 3. Placebo udlaga u ustima pacijentice

\section{Treatment outcomes}

Changes in spontaneous pain were assessed by VAS, changes in oral health quality of life were assessed by the Oral health impact profile (OHIP-14), and the level of perceived stress by Perceived stress scale (PSS). Moreover, the study followed the changes in $\mathrm{MCO}$ for assessing pain-free mouth opening, maximal mouth opening (MMO) for assessing maximal mouth opening and Graded chronic pain scale (GCPS) for assessing characteristic pain intensity. All of the previously mentioned outcomes were measured at all time points. Jaw functional limitation scale (JFLS) scores for assessing functional limitations of the lower jaw were measured at baseline (T0) and at followup appointment at 6th month (T3). GCPS and JFLS questionnaires are part of DC/TMD protocol (13).

\section{Spontaneous pain}

Spontaneous pain was evaluated with a $100 \mathrm{~mm}$ horizontal VAS scale. The left endpoint of the scale $(0 \mathrm{~mm})$ indicated "no pain" while right endpoint of the scale $(100 \mathrm{~mm})$ represented "worst pain imaginable" (14). The subjects with pain of $30 \mathrm{~mm}$ and more were included in the study.

\section{Ishodi liječenja}

Promjene u spontanoj boli praćene su s pomoću ljestvice VAS, kvaliteta života ovisna o oralnom zdravlju procijenjena je upitnikom Oral health Impact Profile (OHIP-14), a stres upitnikom o percipiranom stresu (PSS-om). Također su praćene promjene u iznosu bezbolnog otvaranja (MCOu) i maksimalnom neasistiranom otvaranju usta (MMO-u), a karakteristični intenzitet boli bio je izražen upotrebom graduirane ljestvice kronične boli (GCPS-om). Svi spomenuti ishodi procjenjivani su na svakom kontrolnom pregledu, a ljestvicu ograničenja funkcije čeljusti pacijentice su ispunjavale samo na početnom ( $\mathrm{T}$ 0) i završnom pregledu ( $\mathrm{T} 3$ ). Upitnici GCPS i JFLS dio su protokola DC/TMD-a (13).

\section{Spontana bol}

Za procjenu spontane boli čeljusnoga zgloba i žvačnih mišića korištena je vizualno-analogna ljestvica duljine 100 $\mathrm{mm}$. Njezin raspon kreće se od oznake bez boli $(0 \mathrm{~mm})$ do najgore moguće boli $(100 \mathrm{~mm})$ (14). U studiju su bili uključeni ispitanici koji su bol prema VAS-u ocijenili s $30 \mathrm{~mm}$ i više. 


\section{Maximal mouth opening}

Maximal mouth opening was defined as the maximum distance the participant could open their mouth regardless of the pain they felt, measured as the distance between the upper and lower central incisors.

\section{Maximal comfortable mouth opening}

Maximal comfortable mouth opening (pain-free maximal mouth opening) was measured as the distance between the upper and lower central incisors, and was defined as the maximum distance the participant could open their mouth without experiencing pain or discomfort (12).

\section{Perceived stress}

Perceived stress scale is a 10 -item questionnaire that evaluates subjective perceptions of stress over the previous month. Response options form a 5 -point Likert scale: $0=$ never, $1=$ almost never, $2=$ sometimes, 3 = fairly often, $4=$ very often . Possible scores ranged from $0-40$, with higher scores indicating higher stress levels. The questionnaire was previously translated and validated by Hudek- Knežević etal. (15).

Oral health - related quality of life

The OHIP-14 questionnaire was used to evaluate how TMD-related pain and disability influence patients' quality of life. Patients status was expressed throughout 14 questions, by choosing 1 of the 5 possible answers: $0=$ never, $1=$ hardly ever, $2=$ sometimes, $3=$ fairly often, and $4=$ very often. Possible scores ranged from $0-56$. The questionnaire, previously validated for the evaluation of TMD patients (16), was translated into and validated in Croatian (17).

Graded chronic pain scale - characteristic pain intensity

Graded chronic pain scale was used to evaluate two dimensions of chronic pain severity: pain intensity and painrelated disability. Subscale scores for pain intensity and disability are combined to calculate a chronic pain grade that allows classification of chronic pain patients into 5 categories: grades 0 (pain-free) to IV (high disability-severely limiting). All items are scored on a scale, with responses ranging from $0-10$. Scores are computed and divided into 3 subscales: the characteristic pain intensity score calculated as the mean intensity ratings for reported current, worst, and average pain; the disability score is calculated as the mean rating for difficulty performing daily, social, and work activities; and the disability points score is derived from a combination of ranked categories of number of disability days and disability score $(13,18)$. In our study we evaluated only the changes related to characteristic pain intensity scores.

Jaw functional limitation scale

Jaw functional limitation scale questionnaire is a reliable and valid form that assesses global limitations caused by TMD. The questionnaire consist of 52 items in groupations as follows: a) mastication (20 items), b) vertical jaw mobility (9 items), c) verbal and emotional expression (14 items), and miscellaneous (9 items) (19). In this study we followed the changes in 3 JFLS categories: mastication, vertical jaw mobility and verbal and emotional expression.

\section{Maksimalno neasistirano otvaranje usta}

Maksimalno neasistirano otvaranje usta mjereno je kao udaljenost između maksilarnih i mandibularnih centralnih inciziva, a definirano je kao najveći iznos otvaranja koji pacijent može postići bez obzira na bol i nelagodu.

\section{Maksimalno bezbolno otvaranje usta}

Maksimalno bezbolno otvaranje mjereno je kao udaljenost između maksilarnih i mandibularnih centralnih inciziva, a definirano je kao najveći iznos pri otvaranju usta koji pacijent postigne otvarajući ih bez boli i nelagode (12).

\section{Prcipirani stres}

PSS je standardni upitnik s 10 točaka kojima se procjenjuje subjektivna percepcija stresa u posljednjih mjesec dana. Odgovori se bilježe na ljestvici od 5 točaka: $0=$ nikad, $1=$ gotovo nikad, 2 = katkad, 3 = često, $4=$ vrlo često. Mogući rezultati u rasponu su od 0 do 40 . Upitnik je validiran i preveden u radu Hudeka i Kneževića sa suradnicima (15).

\section{Kvaliteta života ovisna o oralnom zdravlju}

Kratka verzija upitnika OHIP-14 korištena je kako bi se pokazao utjecaj ishoda terapije (stupanj boli i ograničenja) na kvalitetu pacijentova života ovisnu o oralnome zdravlju. Pacijenti su odgovorili na 14 pitanja odabirom jednog od sljedećih odgovora: $0=$ nikad, $1=$ gotovo nikad, $2=$ katkad, 3 = često i 4 = vrlo često. Mogući rezultati u rasponu su od 0 do 56. Upitnik, prije toga validiran za procjenu bolesnika $s$ TMP-om (16), validiran je i preveden na hrvatski jezik (17).

Graduirana ljestvica kronične boli - karakteristični intenzitet boli

Upitnik GCPS upotrebljava se za procjenu dviju dimenzija ozbiljnosti kronične boli - intenziteta boli i ograničenja povezanih s boli. Rezultati karakterističnog intenziteta boli i rezultata nesposobnosti kombiniraju se kako bi se izračunao stupanj kronične boli koji omogućuje klasifikaciju pacijenata u pet kategorija - od 0 (nema boli) do IV (ozbiljna ograničenja). Sve točke sastoje se od ljestvice koja ima vrijednosti od 0 do 10. Rezultati pojedinih točaka zbrajaju se i dijele u tri podljestvice - karakterističan intenzitet boli izračunava se kao aritmetička sredina između intenziteta trenutačne, najgore i prosječne boli; rezultat nesposobnosti računa se kao aritmetička sredina rezultata između točaka koje procjenjuju poteškoće u obavljanju dnevnih, socijalnih i poslovnih aktivnosti; bodovi nesposobnosti dobivaju se zbrajanjem bodova dana nesposobnosti i bodova rezultata nesposobnosti $(13,18)$. U ovoj studiji pratili smo samo promjene karakterističnog intenziteta boli.

\section{Ljestvica funkcijskih ograničenja čeljusti}

Upitnik JFLS pouzdan je i valjan alat kojim se procjenjuju ograničenja uzrokovana temporomandibularnim poremećajima. Sastoji se od 52 točke grupirane na sljedeći način: a) ograničenje žvakanja (20 točaka), b) ograničenje pokretljivosti (9 točaka), c) ograničenje komunikacije (14 točaka), d) druga ograničenja ( 9 točaka) (19).

$\mathrm{U}$ ovom istraživanju pratili smo promjene u trima kategorijama JFLS-a - u ograničavanju žvakanja, ograničavanju pokretljivosti i ograničavanju komunikacije. 


\section{Statistical Analysis}

Data analyses were performed using the Statistica 13.4.0 software package (1984-2018 TIBCO Software Inc.). The distribution of data was tested using the Shapiro-Wilk test. The baseline and 6-month follow-up data (JFLS scores, percentage change of $\mathrm{MCO}$ values and $\mathrm{MMO}$ values) were analyzed means of Student's t-test. The changes in the means of measured variables (VAS, OHIP-14, PSS, GCPS, MCO and MMO scores) were analyzed using repeated measures analysis of variance (ANOVA) with time (baseline, 1st, 3rd, 6th month of therapy) as the within factor and diagnostic subgroups (MP and DD) and type of treatment (SS and PS) as the between factors. Bonferroni's post hoc test was used to show where the differences were found. Eta squared ( $\eta 2$ ) was used to estimate the effect size. A value of $p<0.05$ was considered statistically significant.

\section{Results}

Baseline characteristics did not differ significantly between the two treatment groups when observed in general, as well as when observed in each diagnostic subgroup ( $p>0.05)$. No significant age difference was found between both treatment groups (SS 38.89 \pm 11.79 ; PS $32.66 \pm 11.48$; $t=1.54$, $\mathrm{p}=0.13)$ nor in both treatment groups when divided into diagnostic subgroups: MP subgroup (SS $42.25 \pm 10.06$; PS $36.37 \pm 12.86 \mathrm{t}=1.017, \mathrm{p}=0.33$ ), DD subgroup (SS $36.36 \pm$ 12.88; PS $28.28 \pm 8.81 \mathrm{t}=1.45, \mathrm{p}=0.16)$. Table 1 shows participants' baseline data in both treatment groups.

PSS scores did not differ significantly between diagnostic subgroups $(\mathrm{p}>0.05)$. However, PSS scores changed significantly over time $(\mathrm{p}=0.049$, effect size $=0.11)$ and differed significantly between the two treatment groups $(\mathrm{F}=6.89$, $\mathrm{p}=0.014$ ) with significantly lower values in SS compared to PS group at all follow up appointments (Figure 4).

VAS scores for spontaneous pain showed significant reduction over time (Wilks Lambda $=0.19, \mathrm{~F}=32.70 ; \mathrm{p}=0.0001$, effect size=0.56). Changes in spontaneous pain differed significantly between treatment groups, with greater reduction in the SS compared to the PS group (interaction time x treatment group; Wilks Lambda $=0.58, F=5.78 ; \mathrm{p}=0.004$, effect size $=0.22$ ) (Figure 5). The post hoc analysis showed that in the $S S$ group the mean VAS values were significantly lower at the 1st, 3rd and 6th month of the treatment compared to the baseline ( $p=0.0007, p<0.0001$ and $p<0.0001$ respectively), while in the PS group a significant difference in mean VAS values was found only between 6th month of treatment compared to the baseline $(\mathrm{p}=0.006)$. No statistical significance in VAS scores was present between TMD subgroups.

OHIP-14 scores also showed significant reduction over time (Wilks Lambda $=0.47, \mathrm{~F}=8.80 ; \mathrm{p}=0.0004$, effect size $=0.29)$. Changes in OHIP-14 scores differed significantly between treatment groups, with reduced values only in the SS group during a 6-month period (interaction time $\mathrm{x}$ treatment group; Wilks Lambda $=0.62, \mathrm{~F}=4.32 ; \mathrm{p}=0.02$, effect size $=0.15$ ) (Figure 6). The post hoc analysis showed that in the SS group the mean OHIP-14 scores were significantly lower at the 3rd and 6th month of the treatment compared to the baseline ( $p=0.0009, p<0.0001$ respectively), while in the PS group no significant difference in mean OHIP-14 scores

\section{Statistička analiza}

Podatci su analizirani u statističkom paketu (TIBCO Software Inc., 2018.) Statistica, verzija 13. Za testiranje distribucije podataka korišten je Shapiro-Wilkov test. Početne vrijednosti i vrijednosti tijekom šestomjesečnih kontrola (rezultati upitnika JFLS-a i postotna promjena vrijednosti MCO-a i MMO-a) analizirane su s pomoću Studentova t-testa.

Promjene u prosječnim vrijednostima (VAS, OHIP-14, PSS, GCPS, MCO i MMO) proučene su s pomoću analize ponovljenih mjerenja (ANOVA-om) s čimbenikom vrijeme (T 0, T 1, T 2, T 3) kao izvorom varijabilnosti unutar subjekata te čimbenicima dijagnostička podskupina (MP-om i DD-om) i vrsta terapije (SU-om i PU-om) kao izvorima varijabilnosti između subjekata, nakon čega su slijedili post hoc Bonferronijevi testovi. Eta kvadrat $\left(\eta^{2}\right)$ služio je u procjeni veličine efekta. Statistički značajnom smatrala se vrijednost $\mathrm{p}<0,05$.

\section{Rezultati}

Nisu zabilježene statistički značajnije razlike među terapijskim skupinama prije početka liječenja, ali ni među terapijskim skupinama kada su bile podijeljene u dijagnostičke podskupine $(\mathrm{p}>0,05)$. Također nije bilo značajne razlike $\mathrm{u}$ dobi pacijentica između dviju terapijskih skupina (SU 38,89 \pm 11,79; PU 32,66 $\pm 11,48 ; \mathrm{t}=1,54, \mathrm{p}=0,13)$, ni između dijagnostičkih podskupina s TMP-om: u podskupini s MP-om (SU 42,25 $\pm 10,06 ;$ PU 36,37 $\pm 12,86 \mathrm{t}=1,017, \mathrm{p}=0,33) \mathrm{i}$ u podskupini s DD-om (SU 36,36 $\pm 12,88$; PS 28,28 $\pm 8,81$ $\mathrm{t}=1,45, \mathrm{p}=0,16)$. Osnovne karakteristike pacijentica pri podjeli u terapijske skupine nalaze se u tablici 1 .

Rezultati PSS-a nisu se značajno razlikovali između dijagnostičkih podskupina $(p>0,05)$. Međutim, rezultati PSS-a s vremenom su se značajno smanjili ( $\mathrm{p}=0,049$, veličina efekta $=0,11$ ), a u skupini SU na svim su kontrolnim pregledima zabilježene značajno niže PSS vrijednosti u usporedbi s PU skupinom $(\mathrm{F}=6,89, \mathrm{p}=0,014)$ (slika 4.).

Vrijednosti boli, procjenjivane prema ljestvici VAS, značajno su se smanjile tijekom vremena (Wilksova lambda = $0,19, \mathrm{~F}=32,70 ; \mathrm{p}=0,0001$, veličina efekta $=0,56$ ). Promjene u spontanoj boli značajno su se razlikovale između terapijskih skupina, pri čemu je veće smanjenje bilo zabilježeno u skupini sa SU-om negoli u onoj s PU-om (interakcija vrijeme $x$ terapijska skupina; Wilksova lambda $=0,58, F=5,78 ; p$ $=0,004$, veličina efekta $=0,22$ ). Post hoc analiza pokazala je da su u skupini sa SU-om srednje vrijednosti VAS-a bile značajno niže u prvom, trećem i šestom mjesecu terapije u odnosu prema početnim vrijednostima $(\mathrm{p}=0,0007, \mathrm{p}<0,0001 \mathrm{i}$ $\mathrm{p}<0,0001$ respektivno), a značajna je razlika u odnosu prema početnom mjerenju pronađena u skupini s PU- samo na posljednjem mjerenju (sesti mjesec terapije) $(p=0,006)$. Nije bilo značajnih razlika u vrijednostima VAS-a između dijagnostičkih podskupina (slika 5.).

Rezultati upitnika OHIP-14 također su se smanjili tijekom vremena (Wilksova lambda $=0,47, F=8,80 ; p=0,0004$, veličina efekta $=0,29)$. Promjene u OHIP-u 14 u vrijednostima su se značajno razlikovale između terapijskih skupina, sa značajno nižim vrijednostima tijekom terapijskog razdoblja u skupini sa SU-om (interakcija vrijeme x terapijska skupina; Wilksova lambda $=0,62, \mathrm{~F}=4,32 ; \mathrm{p}=0,02$, veličina efekta $=$ $0,15)$. Post hoc analiza pokazala je da su u skupini sa SU-om 
Table 1 Demographics and baseline data of participants

Tablica 1. Demografski i polazni podaci o ispitanicima

Variable • varijabla

(To)

\begin{tabular}{|c|c|c|c|c|}
\hline (To) & $\begin{array}{l}\text { Stabilization splint } \bullet \\
\text { stabilizacijska udlaka } \\
\qquad(\mathrm{N}=19)\end{array}$ & $\begin{array}{l}\text { Placebo splint * } \\
\text { placebo udlaga } \\
\qquad(\mathrm{N}=15)\end{array}$ & $t$ & $\mathbf{p}$ \\
\hline dob • age & $38.89 \pm 11.79$ & $32.66 \pm 11.48$ & 1.54 & 0.13 \\
\hline PSS & $17.63 \pm 6.05$ & $19.73 \pm 7.22$ & 0.92 & 0.36 \\
\hline GCPS & $49.42 \pm 20.98$ & $46.20 \pm 15.89$ & 0.49 & 0.62 \\
\hline OHIP-14 & $26.31+9.99$ & $22.13+11.96$ & 1.11 & 0.27 \\
\hline IFIS Z̃vakanje $\cdot$ mastication & $3.87 \pm 2.34$ & $2.93+1.80$ & 1,28 & 0.20 \\
\hline IfIS pokretnost donje celjusti • jaw mobility & $4.85 \pm 1.73$ & $3.96 \pm 1.67$ & 1.50 & 0.14 \\
\hline $\begin{array}{l}\text { JFLS verbalna i neverbalna kamunikacija - } \\
\text { verbal and emotional expression }\end{array}$ & $1.75 \pm 1.66$ & $1.28 \pm 1.28$ & 0.90 & 0.37 \\
\hline $\mathrm{MCO}(\mathrm{mm})$ & $27.57 \pm 9.88$ & $27.93 \pm 6.18$ & -0.12 & 0.90 \\
\hline MMO (mm) & $35.78 \pm 9.12$ & $36.86 \pm 6.41$ & -0.38 & 0.70 \\
\hline VAS & $6.52 \pm 2.03$ & $5.53 \pm 1.72$ & 1.50 & 0.14 \\
\hline
\end{tabular}

\section{Stabilization splint •}

abilizacijska udlaga $(\mathrm{N}=19)$
Placebo splint •

placebo udlapa

$(\mathrm{N}=15)$

PS5, porcoived stross scalo/samo-percipirajudi stres; GCPS, graded chronic pain scalo/skala gradacijo kroniene boll; OHIP-14, oral health impact factor/profil 23 procionu oraineg zdravlij: JFLS, jaw function limitation scale/skala ogranizenia funkcilo donie collustij MCo maximal comfortable mouth opening/maksimalno bezbolno otvaranje; MMO maximai mouth opening/ maksimalno moguce otvaranje usta: vAS, visuat analokue scale/vizualnoanalogna skala; To, baseline variables/pozetne varijable

4

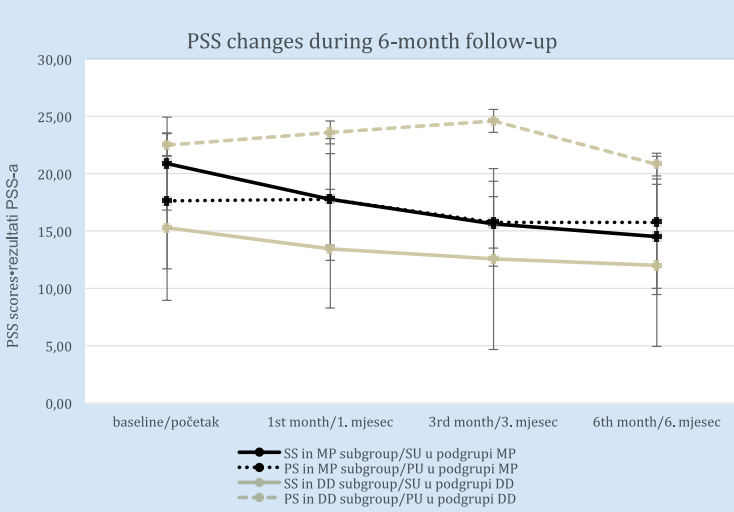

6

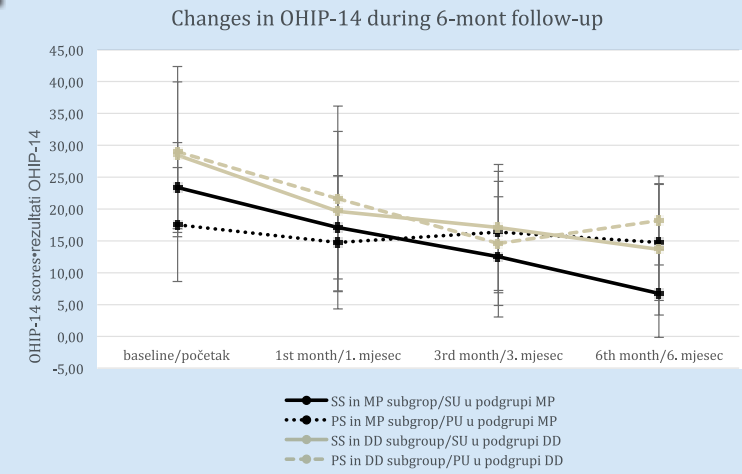

5

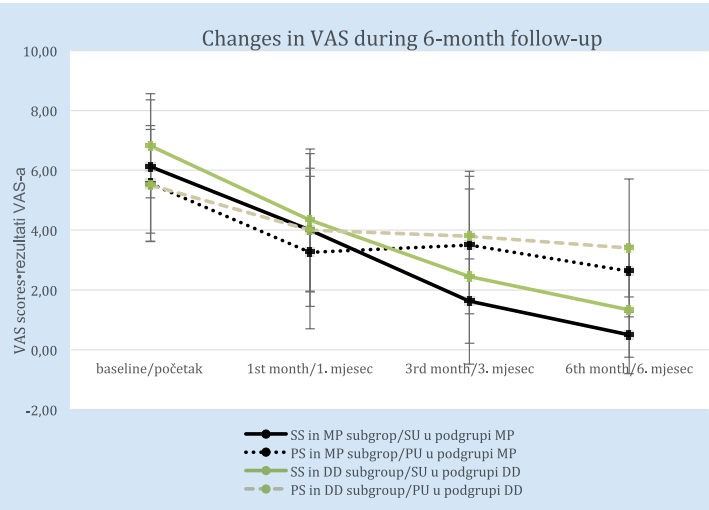

Changes in MCO during 6-month follow-up

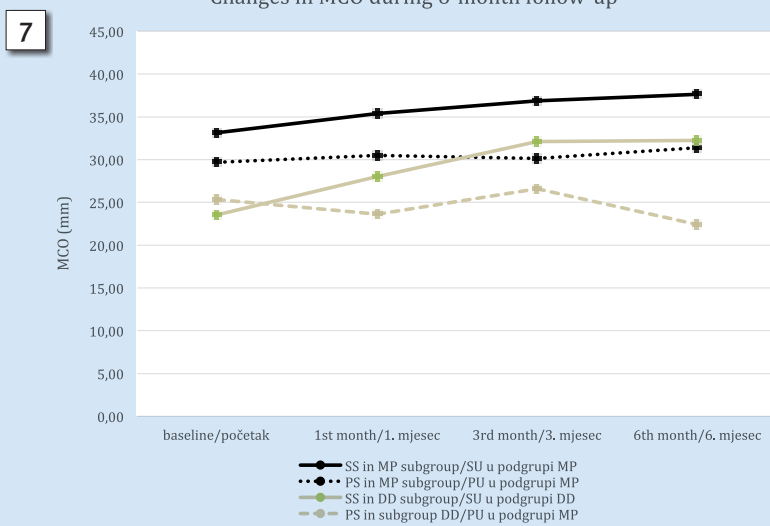

Figure 4 Changes in self-perceived stress (PSS) from baseline to 6th month of the therapy. SS stabilization splint; PS placebo splint; MP myofascial pain subgroup; DD disc displacement subgroup

Slika 4. Promjene percipiranog stresa (PSS) od polaznih rezultata do 6. mjeseca liječenja. SU stabilizacijska udlaga; PU placebo udlaga; MP podgrupa miofascijalna bol; DD podgrupa pomak zglobne pločice

Figure 5 Changes in spontaneous pain (VAS) from baseline to 6th month of the therapy. SS stabilization splint; PS placebo splint; MP myofascial pain subgroup; DD disc displacement subgroup

Slika 5. Promjene spontane boli (VAS) od polaznih rezultata do 6. mjeseca liječenja. SU stabilizacijska udlaga; PU placebo udlaga; MP podgrupa miofascijalna bol; DD podgrupa pomak zglobne pločice

Figure 6 Changes in oral health-related quality of life (OHIP-14) from baseline to 6th month of the therapy. SS stabilization splint; PS placebo splint; MP myofascial pain subgroup; DD disc displacement subgroup

Slika 6. Promjene u kvaliteti života povezanoj s oralnim zdravljem (OHIP-14) od polaznih rezultata do 6. mjeseca liječenja. SU stabilizacijska udlaga; PU placebo udlaga; MP podgrupa miofascijalna bol; DD podgrupa pomak zglobne pločice

Figure 7 Changes in maximal comfortable mouth opening (MCO) from baseline to 6th month of the therapy. SS stabilization splint; PS placebo splint; MP myofascial pain subgroup; DD disc displacement subgroup

Slika 7. Promjene u maksimalnom bezbolnom otvaranju usta (MCO) od polaznih rezultata do 6. mjeseca liječenja. SU stabilizacijska udlaga; PU placebo udlaga; MP podgrupa miofascijalna bol; DD podgrupa pomak zglobne pločice 

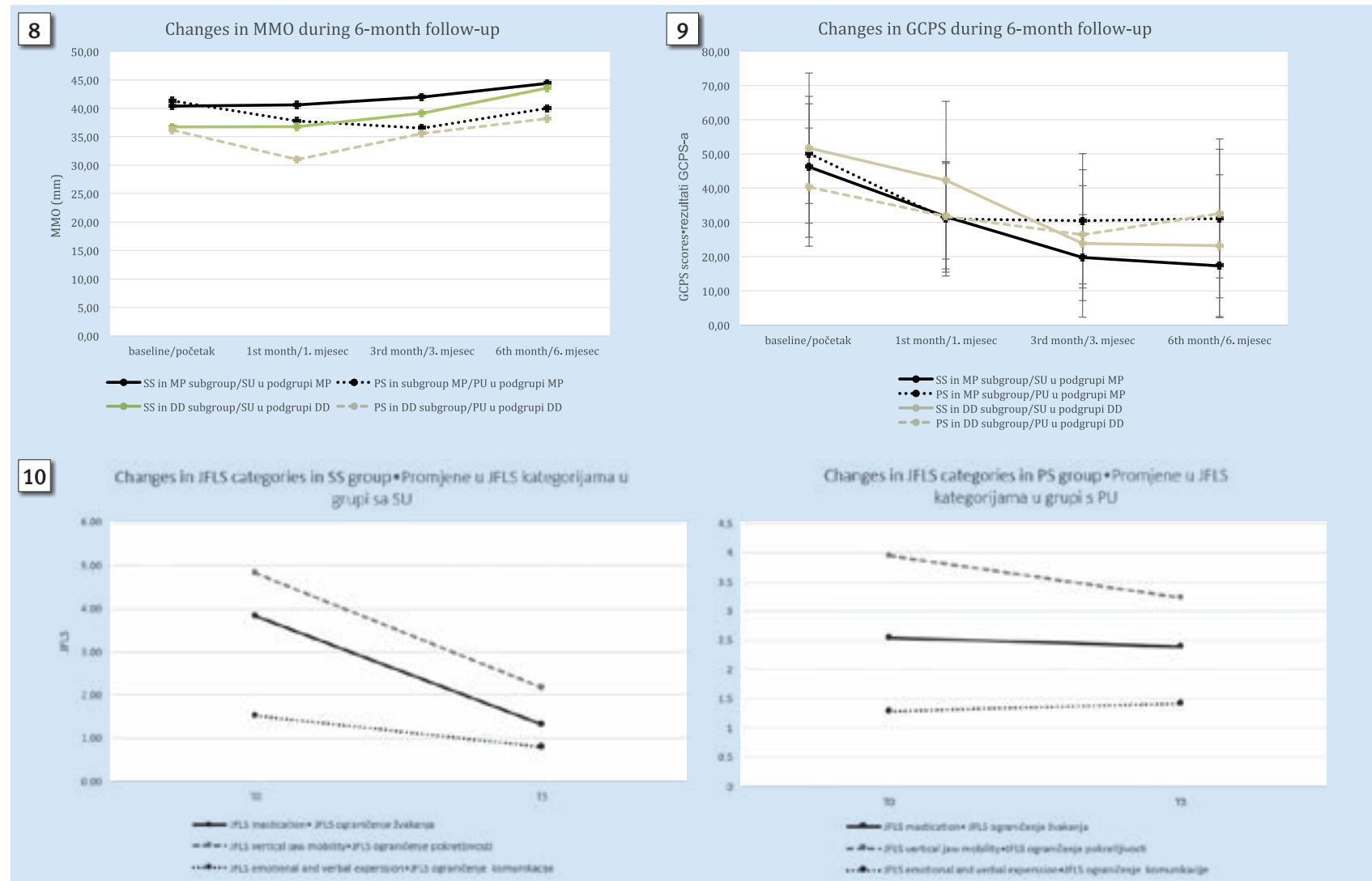

Figure 8 Changes in maximal mouth opening (MMO) from baseline to 6th month of the therapy. SS stabilization splint; PS placebo splint; MP myofascial pain subgroup; DD disc displacement subgroup

Slika 8. Promjene u maksimalnom otvaranju usta (MMO) od polaznih rezultata do 6. mjeseca liječenja. SU stabilizacijska udlaga; PU placebo udlaga; MP podgrupa miofascijalna bol; DD podgrupa pomak zglobne pločice

Figure 9 Changes in characteristic pain-intensity (GCPS) from baseline to 6th month of the therapy. SS stabilization splint; PS placebo splint; MP myofascial pain subgroup; DD disc displacement subgroup

Slika 9. Promjene u karakterističnom intenzitetu boli (GCPS) od polaznih rezultata do 6. mjeseca liječenja. SU stabilizacijska udlaga; PU placebo udlaga; MP podgrupa miofascijalna bol; DD podgrupa pomak zglobne pločice

Figure 10 Changes in JFLS categories between the baseline measurements (T0) and the last measurements (T3).

Slika 10. Promjene pojedinih kategorija JFLS upitnika između početnog mjerenja (T0) i završnog mjerenja (T3).

Figure 10a Changes in JFLS categories in stabilization splint group (SS).

Slika 10a. Promjene pojedinih kategorija JFLS u skupini sa stabilizacijskom udlagom (SU)

Figure 10b Changes in JFLS categories in placebo splint group (PS).

Slika 10b. Promjene pojedinih kategorija JFLS u skupini s placebo udlagom (PU).

was present between baseline and follow-up appointments. No statistical significance in OHIP-14 scores was found considering theTMD subgroups.

MCO values did not change significantly over time, however pain-free maximal mouth opening differed significantly between the two treatment groups $(\mathrm{F}=4.37, \mathrm{p}=0.046)$ with greater overall values in the SS group (Figure 7). Also, a significant difference was found when comparing the MP group to the $\mathrm{DD}$ group with greater overall values in the MP group $(F=5.42, p=0.03)$. Significant difference in percentage change in MCO between the two treatment groups with greater increase in the SS group was found (SS 28.54\%; PS $1.64 \% ; \mathrm{t}=2.11 \mathrm{p}=0.043$ ).

$\mathrm{MMO}$ values did not differ significantly between the two treatment groups or the diagnostic subgroups $(\mathrm{p}>0.05)$ but they changed significantly over time (Wilks Lambda $=0.72$, $\mathrm{F}=3.16 ; \mathrm{p}=0.042$, effect size $=0.12$ ). Although the changes in MMO values did not differ significantly between the two treatment groups, a tendency of constant increase of MMO was present in the SS group (Figure 8). Also, a significant vrijednosti OHIP-a 14 bile značajno niže treći i šesti mjesec terapije $\mathrm{u}$ odnosu prema početnim vrijednostima $(\mathrm{p}=0,0009$, $\mathrm{p}<0,0001$ respektivno), a u skupini s PU-om nije bilo značajnih razlika između početnog mjerenja i mjerenja na kontrolnim pregledima. Nije bilo značajnih razlika u vrijednostima u OHIP-u 14 između dijagnostičkih podskupina (slika 6.).

Tijekom šestomjesečnog razdoblja nije zabilježeno statistički značajno povećanje iznosa maksimalnog bezbolnog otvaranja usta (MCO-a), no u skupini sa SU-om zabilježene su značajno više vrijednosti bezbolnog otvaranja usta u odnosu prema skupini s PU-om $(\mathrm{F}=4,37, \mathrm{p}=0,046)$. Značajna razlika u vrijednostima MCO-a također je bila zabilježena između skupina s MP-om i DD-om, $s$ većim vrijednostima u skupini s MP-om $(\mathrm{F}=5,42, \mathrm{p}=0,03)$ (slika 7.).

Pronađena je značajna razlika u postotnoj promjeni vrijednosti MCO-a između dviju terapijskih skupina, $s$ većim povećanjem opsega otvaranja u skupini sa SU-om (SU 28,54; PU 1,63; t = 2,11 p = 0,043).

Nisu zabilježene značajne razlike u vrijednostima maksimalnog neasistiranog otvaranja usta među terapijskim skupi- 
difference in percentage change in MMO between the two treatment groups with greater increase in the SS group was found (SS 23.82\%; PS 0.73\%; $\mathrm{t}=2.32$, $\mathrm{p}=0.028$ ).

GCPS scores did not differ significantly between treatment groups or the diagnostic subgroups but decreased significantly over time (Wilks Lambda $=0.45, F=9.52 ; \mathrm{p}=0.0003$, effect size $=0.35$ ) (Figure 9).

All JFLS categories, except emotional and verbal expression, showed significant decrease between baseline measurements (T0) and the last time-point measurements (T3) in the SS group (mastication $\mathrm{t}=4.92$, $\mathrm{p}=0.00015$; vertical jaw mobility $\mathrm{t}=4.82, \mathrm{p}=0.00018$; emotional and verbal expression $\mathrm{t}=1.82, \mathrm{p}=0.086$ ). No such changes in JFLS categories were observed in the PS group (mastication $\mathrm{t}=0.24, \mathrm{p}=0.81$; vertical jaw mobility $\mathrm{t}=1.26, \mathrm{p}=0.23$; emotional and verbal expression $\mathrm{t}=-0.24, \mathrm{p}=0.56$ ) (Figure 10 ).

\section{Discussion}

Studies that tried to compare the effect of placebo therapy with stabilization splint have sometimes yielded conflicting results. Some researchers attempted to equate the effect of stabilization with that of placebo devices encouraging the debate on the real value of the specific design of the stabiliztation splint. In these studies, the placebo splint is often a "nonsplint" designed as non-occluding device $(20,21)$.

In our research, starting with the assumption that patients may recognize non-occluding device as placebo, we took a slightly different approach. Since it is speculated that therapy value of SS lies in increasing of vertical dimension and changing of condylar position $(22,23,24,25)$, we used very thin thermoforming foil that covered occlusal surfaces but did not provide occlusion in CR position. In addition, the effect on the vertical dimension wasn't notable, therefore when biting patients were in their habitual occlusion position vertically increased for less than $0.5 \mathrm{~mm}$. With Michelotti et al. pointing out that counselling may be as successful modality as splint therapy (12), we informed both groups equally about the origin and prognosis of the disease, thus making the applied therapy the only diversity between groups.

Our results showed that changes in spontaneous pain and oral health related quality of life differed significantly between patients treated with stabilization splint as compared to patients treated with placebo splint, with greater reduction through all 6 months found in the SS group. In addition, significant improvement in the SS group after 6th month of treatment compared to baseline was present in all JFLS categories, except emotional and verbal expression.

We may say that SS provided better continuous, longterm therapeutic effect. PS performed very well in reduction of spontaneous pain in the short term, however reduction of OHIP-14 and JFLS scores was found only in the SS group nama, ni među dijagnostičkim podskupinama ( $p>0,05)$, no tijekom terapije zabilježeno je statistički značajno povećanje vrijednosti MMO-a (Wilksova lambda $=0,72, \mathrm{~F}=3,16 ; \mathrm{p}=$ 0,042 , veličina efekta $=0,12$ ). Iako se vrijednosti MMO-a nisu značajno razlikovale među terapijskim skupinama, uočena je tendencija kontinuiranog povećanja vrijednosti MMO-a u skupini sa SU-om (slika 8.). Također je pronađena značajna razlika u postotnoj promjeni vrijednosti MMO-a između dviju terapijskih skupina, $s$ izraženijim povećanjem u skupini sa SU-om (SS 23,82 \%; PS 0,73\%; t = 2,32, p = 0,028).

Tijekom terapije značajno su smanjene vrijednosti GCPS-a (Wilksova lambda $=0,45, F=9,52 ; p=0,0003$, veličina efekta $=0,35)$. Promjene u vrijednostima GCPS-a nisu se značajno razlikovale ni između terapijskih skupina, ni između dijagnostičkih podskupina (slika 9.).

U skupini sa SU-om pronađena je značajna razlika između početnih vrijednosti (T 0) i završnih mjerenja (T 3) za sve ispitane u kategoriji JFLS-a, osim u kategoriji ograničenje komunikacije, (žvakanje $\mathrm{t}=4,92, \mathrm{p}=0,00015$; pokretljivost $\mathrm{t}=$ $4,82, p=0,00018$; komunikacija $t=1,82, p=0,086)$. U skupini s PU-om nije bilo značajnih promjena u pojedinim kategorijama JFLS-a. (žvakanje $\mathrm{t}=0,24, \mathrm{p}=0,81$; pokretljivost $\mathrm{t}$ $=1,26, \mathrm{p}=0,23$; komunikacija $\mathrm{t}=-0,24, \mathrm{p}=0,56)$ (slika 10.).

\section{Rasprava}

U istraživanjima u kojima se pokušala usporediti uspješnost placebo terapije i terapije stabilizacijskom udlagom u liječenju pacijenata s temporomandibularnim poremećajima nisu dobiveni jednoznačni rezultati. U nekima autori nisu uspjeli dokazati razlike u terapijskoj djelotvornosti stabilizacijske udlage i placebo udlage te su potaknuli raspravu o stvarnom učinku i vrijednosti karakterističnog oblikovanja stabilizacijske udlage. Placebo udlaga u istraživanjima često se odnosi na neokludirajuću udlagu oblikovanu kao nepčana ploča koja ne pokriva okluzijske plohe zuba $(20,21)$.

Kako smo pretpostavili da bi pacijenti mogli prepoznati neokluzijsku udlagu kao udlagu koja nema terapijski učinak, u planiranju terapije pristupili smo nešto drukčije. $S$ obzirom na to da se terapijski učinak SU-a pripisuje povećanoj vertikalnoj dimenziji okluzije te karakterističnom položaju kondila $(22,23,24,25)$, za izradu placebo udlage upotrijebili smo vrlo tanku termoformirajuću foliju koja je pokrila okluzijske plohe zuba, ali nije omogućila odnos gornje i donje čeljusti u CR-u, a utjecaj na povećanje vertikalne dimenzije okluzije bio je zanemariv jer je vertikalna dimenzija okluzije povećana za manje od $0,5 \mathrm{~mm}$. S obzirom na to da su Michelotti i suradnici zaključili da je informiranje pacijenata jednakovrijedna terapijska metoda stabilizacijskoj udlazi (12), pacijentice u objema skupinama na isti su način obaviještene o temporomandibularnom poremećaju te je tako korištena udlaga bila jedina terapijska različitost između skupina.

Naši rezultati pokazali su veće smanjenje spontane boli i veće poboljšanje kvalitete života ovisne o oralnome zdravlju kod pacijenata tijekom liječenja u skupini sa SU-om u odnosu na onu s PU-om. Također je nakon šest mjeseci terapije bilo zabilježeno značajno poboljšanje u skupini sa SU-om i to u svim kategorijama JFLS-a, osim u kategoriji ograničenje komunikacije. 
across a 6-month period. It is interesting to note that graphic representation of PS performance during 6-month treatment in Figures 5, 6 and 9 resemble the graphic representation of SS but after 3rd month it is followed by either plateau or even mild deterioration towards the higher values. Regardless of the potentially negligible effect of the slightly increased vertical dimension of less than $0.5 \mathrm{~mm}$, the design of the placebo device should be taken into consideration when interpreting these results since all the changes in vertical positioning of the lower jaw might affect the treatment outcomes. We may conclude that both SS and PS were effective in management of spontaneous pain. This could be attributed to prior education of patients on the disorder (12) or the fact that even a slight increase in vertical dimension can provide the muscle rearrangement leading to a relaxation of the elevator muscles and consequently, reduction of the pain. Significant differences between the treatment groups in improvement of pain and quality of life could be due to the fact that SS was thicker (providing a greater increase in vertical dimension of occlusion), as well as constructed to provide CR occlusion and specific condylar position, thus contributing to the relief of the TMJ $(7,9)$.

An interesting finding was that most of the mentioned parameters did not differ significantly between the TMD subgroups except the $\mathrm{MCO}$ with better results in the MP group. The reason for better improvement of the $\mathrm{MCO}$ results in the MP when comparing to the DD subgroup is probably the fact that in the DD group the biological barrier (displaced disc) is blocking the condyle without the possibility for restoring its position (26), thus limiting the full range of opening.

PSS scores differ significantly between treatment groups, and changed significantly over time. The decreased PSS scores showed that psychological stress, considered the predisposing factor for TMD (27), was positively affected by treatment duration.

Similar long-term effectiveness of SS was found by Ekberg et al. They monitored patients over 6 and 12 months and recommended the SS appliance for further use in TMD management (28). Moreover, Alajbeg et al. found that, when compared to placebo and amitriptyline therapy, SS showed a significantly greater change in the MCO (29). Still, in studies with the goal to compare TMD treatment options, patients have been monitored over different time periods, hence the inconsistent results can be attributed to different therapy duration. Furthermore, the design of occlusal or nonocclusal devices differ to a great extent and it is difficult to provide comparable results $(20,21,28,29)$.

The limitation of the present study lies in the fact that only female experiencing chronic, moderate to severe pain, whose response to the therapy may be different than in those with mild pain, were included in the study. However, the main advantage of the study was that we carefully selected and followed the subjects for a longer period of time with validated and widely accepted TMD diagnostic questionnaires and protocols, whereby our results showed that the specific design of the stabilization splint contributes to the treatment of TMD.
Stabilizacijska udlaga imala je značajan utjecaj na smanjenje simptoma i pružala je kontinuirani, dugotrajni terapijski učinak. Placebo udlaga imala je kratkoročan učinak na smanjenje spontane boli, no smanjenje vrijednosti OHIP-a 14 te iznosa pojedinih kategorija JFLS-a tijekom šestomjesečne terapije bilo je zabilježeno samo u skupini sa SU-om. Zanimljivo je primijetiti kako se grafički prikaz djelotvornosti PU-a na slikama 5., 6. i 9. kreće jednako kao i kod SU-a, no nakon trećeg mjeseca slijedi blago pogoršanje prema većim iznosima. Bez obzira na potencijalno zanemariv učinak povišene vertikalne dimenzije okluzije za manje od $0,5 \mathrm{~mm}$ pri oblikovanju placebo udlage, pri interpretaciji rezultata treba uzeti u obzir svaku promjenu u vertikalnom odnosu gornje i donje čeljusti zbog njezina potencijalnog utjecaja na ishod terapije. Početno smanjenje simptoma TMP-a, vidljivo u objema terapijskim skupinama, može biti posljedica informiranja pacijenata o poremećaju za koji je dokazano da pozitivno utječe na smanjenje simptoma (12) ili činjenice da se čak i zbog vrlo diskretnog povišenja vertikalne dimenzije okluzije može dogoditi promjena u mišićima koja za posljedicu ima opuštanje mišića podizača čeljusti i naposljetku smanjenje boli.

Razlike koje postoje kada promatramo odnose između terapijskih skupina možda se pojavljuju zbog specifičnog dizajna SU-a koji je deblji od PU-a i zbog toga značajnije povisuje vertikalnu dimenziju okluzije. Također je oblikovan tako da donju čeljust smješta u CR, a kondile u položaj koji rezultira rasterećenjem TMZ-a $(7,9)$.

Zanimljivo je da se većina mjerenih parametara nije značajno razlikovala između dijagnostičkih podskupina TMP-a, osim vrijednosti MCO-a koje su bile značajno više u skupini s MP-om. Razlog za razliku u vrijednostima MCO-a između skupina s MP-om i DD-om vjerojatno je pomaknuti disk u podskupini s DD-om koji čini biološku barijeru i najvjerojatnije ne postoji mogućnost da se vrati u prijašnje fiziološko stanje (26). Na taj način ograničeno je vraćanje punog raspona otvaranja usta u podskupini s DD-om.

Vrijednosti PSS-a razlikovale su se između terapijskih skupina, te se dogodio značajniji pad tijekom vremena. Značajan pad vrijednosti PSS-a pokazuje kako je na psihološki stres, rizični čimbenik TMP-a (27), terapijsko razdoblje od šest mjeseci imalo pozitivan učinak.

Ekberg i suradnici pratili su pacijente tijekom šest i dvanaest mjeseci te uočili sličan dugotrajni terapijski uspjeh SUa. Preporučili su SU za daljnje korištenje u terapiji TMPa (28). Alajbeg i suradnici uspoređivali su terapijski učinak amitriptilina, placebo lijeka i SU-a, te pokazali da se jedino u skupini liječenoj SU-om značajno povećao MCO (29). Poteškoće u interpretaciji usporedbe rezultata ovoga i sličnih istraživanja proizlaze iz činjenice da su istraživanja provedena u različitim vremenskim razdobljima, stoga su inkonzistentni rezultati vjerojatno posljedica različitog trajanja terapije, a i posljedica konstrukcija istraživanih udlaga koje se razlikuju u velikoj mjeri i onemogućuju kvalitetnu usporedbu rezultata $(20,21,28,29)$.

Ispitnu i kontrolnu skupinu činile su samo žene s kroničnom, srednje jakom do jakom boli. Kako ishodi terapije mogu biti različiti u skupini s blagom boli, spomenuto se može smatrati otegotnim čimbenikom u istraživanju.

Kao najveću prednost istraživanja istaknuli bismo pažljivo biranje i praćenje ispitanika tijekom duljeg razdoblja, pri 


\section{Conclusion}

Due to significant improvement in spontaneous pain, health-related quality of life and functional limitations of the lower jaw in group treated with stabilization splint compared to placebo, we may conclude that stabilization splint showed better treatment effectiveness during a 6-month period. Moreover, significantely higher values of pain-free mouth opening were observed in patients treated with stabilization splint. Placebo might be partly responsible for improving spontaneous pain, probably even comparable with the effect of active therapy when observed in a short period of time, however, it seems that it cannot maintain a continual longterm positive therapeutic effect.

\section{Acknowledgements}

This work has been fully supported by the Croatian Science Foundation Project "The Role of Oxidative Stress and Opiorphin in Temporomandibular Disorders" (No. IP2014-09-3070), Operational Programme "Efficient Human Resources 2014-2020”, and European Social Fund within the "Young Researchers' Career Development Project Training of Doctoral Students".

Details are available at

http://www.hrzz.hrldefault.aspx?id=780 amp;pid=3070\&amp ;rok $=2014-09$

\section{Conflict of interest}

The authors report no conflict of interest čemu smo se koristili validiranim i općeprihvaćenim dijagnostičkim upitnicima i protokolima, čime smo pokazali kako je specifičan oblik stabilizacijske udlage terapijska vrijednost za temporomandibularne poremećaje.

\section{Zaključak}

S obzirom na to da je u skupini liječenoj stabilizacijskom udlagom znatnije smanjena spontana bol, poboljšala se kvaliteta života te funkcija donje čeljusti u usporedbi sa skupinom liječenom placebo udlagom, možemo zaključiti da je stabilizacijska udlaga pokazala bolju učinkovitost tijekom šestomjesečnog liječenja. U skupini liječenoj stabilizacijskom udlagom također su uočene značajno veće vrijednosti maksimalnoga bezbolnog otvaranja usta. Iako bi placebo mogao biti dijelom odgovoran za poboljšanje simptoma TMP-a, vjerojatno ne može zadržati kontinuirani dugoročni pozitivni terapijski učinak.

\section{Potpora}

Ovo istraživanje financirano je u sklopu projekata Uloga oksidativnog stresa i opiorfina u temporomandibularnim poremé́ajima (No. IP- 2014-09-3070) Hrvatske zaklade za znanost (HRZZ-a) Ucinkoviti ljudski potencijali 2014. - 2020. i Europskoga socijalnog fonda Projekt za razvoj karijera mladih istraživača - izobrazba novih doktora znanosti.

Detalji dostupni na:

http://www.hrzz.hrldefault.aspx?id=786amp;pid=3070むamp ;rok=2014-09

\section{Sukob interesa}

Nije bilo sukoba interesa.

\section{Sažetak}

Svrha istraživanja: Cilj ove studije bio je procijeniti dugoročnu učinkovitost stabilizacijske udlage u liječenju pacijenata s kroničnim temporomandibularnim poremećajima (TMP-om) te usporediti ishode liječenja s onima postignutima placebo udlagom kod pacijenata s dijagnozom miofascijalne boli onih s pomakom zglobne pločice. Materijali i metode: $U$ dvije terapijske skupine bile su podijeljene 34 pacijentice s kroničnim TMP-om - u prvoj su se skupini, kao terapijskim sredstvom, koristile stabilizacijskom udlagom (SU-om), a u drugoj placebo udlagom (PU-om). Ishodi liječenja (bol procijenjena vizualnom analognom ljestvicom (VAS-om), maksimalno bezbolno otvaranje usta (MCO), maksimalno neasistirano otvaranje usta (MMO), kvaliteta života ovisna o oralnome zdravlju (OHIP-14), razina percipiranog stresa (PSS), karakteristični intenzitet boli (prema graduiranoj ljestvici kronične boli GCPS-u) i funkcijska ograničenja čeljusti (prema ljestvici ograničenja funkcije čeljusti -JFLS-u) praćeni su tijekom šest mjeseci. Rezultati: Nisu zabilježene statistički značajnije razlike među skupinama prije početka liječenja $(p>0,05)$. Rezultati procijenjeni VAS-om i srednji rezultati za OHIP-14 značajno su se razlikovali između terapijskih skupina ( $p=0,004, p=0,02$, respektivno), $s$ većim smanjenjem boli i većim poboljšanjem kvalitete života u skupini sa SU-om u odnosu na skupinu s PU-om. Tijekom šest mjeseci nije zabilježeno statistički značajno povećanje iznosa maksimalnoga bezbolnog otvaranja usta (MCO), no vrijednosti MCO-a značajno su se razlikovale između terapijskih skupina, $s$ većim ukupnim vrijednostima u skupini sa SU-om u usporedbi s onom s PU-im $(p=0,046)$, te između dijagnostičkih podskupina s TMP-om, s većim ukupnim vrijednostima u skupini s MP-om u odnosu prema skupini s DD bolesnicima $(p=0,03)$. U skupini sa SU-om postojala je značajna razlika u kategorijama JFLS-a između početne vrijednosti i nakon šest mjeseci liječenja u svim kategorijama, osim u emocionalnoj i verbalnoj ekspresiji (žvakanje $p=0,00015$; okomita pokretljivost čeljusti $p=$ 0,00018 ). U skupini s PU-om nije bilo značajnih promjena u pojedinim kategorijama JFLS-a. Zaključak: Tijekom šestomjesečnog liječenja stabilizacijska udlaga pokazala se učinkovitijom od placebo udlage u smanjenju spontane boli, funkcionalnih ograničenja donje čeljusti te u poboljšanju kvalitete života ovisne o oralnome zdravlju. U skupini liječenoj stabilizacijskom udlagom također su uočene značajno veće vrijednosti maksimalnoga bezbolnog otvaranja usta. lako bi placebo mogao dijelom biti odgovoran za poboljšanje simptoma TMP-a, vjerojatno ne može zadržati kontinuirani dugoročni pozitivni terapijski učinak.
Zaprimljen: 16. svibnja 2019 Prihvaćen: 21. kolovoza 2019

Adresa za dopisivanje Ema Vrbanović, dr. med. dent. Sveučilište u Zagrebu Stomatološki fakultet Zavod za mobilnu protetiku Gundulićeva 5, HR-10 000 Zagreb evrbanovic@sfzg.hr

Ključne riječi

temporomandibularni poremećaji, okluzijska udlaga, kronična bol, facijalna bol 


\section{References}

1. Gauer RL, Semidey MJ. Diagnosis and Treatment of temporomandibular disorders. Am Fam Physician. 2015 Mar 15;91(6):378-86

2. Reiter S, Goldsmith C, Emodi-Perlman A, Friedman-Rubin P, Winocur E. Masticatory muscle disorders diagnostic criteria: The American Academy of Orofacial Pain versus the research diagnostic criteria/temporomandibular disorders. J Oral Rehabil. 2012 Dec;39(12):941-7.

3. Stohler CS. Muscle-related temporomandibular disorders. J Orofac Pain. 1999;13(4):273-284.

4. Warren M, Fried JL. Temporomandibular disorders and hormones in women. Cells Tissues Organs. 2001;169:187-192.

5. Peck CC, Goulet JP, Lobbezoo F, Schiffman EL, Alstergren P, An derson GC, et al. Expanding the taxonomy of the diagnostic criteria for temporomandibular disorders. J Oral Rehabil. 2018 Mar;45(3):258-268.

6. Wieckiewicz M, Boening K, Wiland P, Shiau YY, Paradowska-Stolarz A. Reported concepts for the treatment modalities and pain management of temporomandibular disorders. J Headache Pain. 2015;16:106.

7. Klasser GD, Greene CS. Oral appliances in the management of temporomandibular disorders. Oral Surg Oral Med Oral Pathol Oral Radiol Endod. 2009;107(2):144-150.

8. Al-Ani Z, Gray RJ, Davies SJ, Sloan P, Glenny AM. Stabilization Splint Therapy for the Treatment of Temporomandibular Myofascial Pain: A Systematic Review. J Dent Educ. 2005 Nov;69(11):1242-50.

9. Gray RJ, davies SJ, Quayle AA. A clinical approach to temporomandibular disorders: a clinical approach to treatment. $\mathrm{Br}$ Dent J. 1994 Sep 10;177(5):171-8.

10. Türp JC, Komine F, Hugger A. Efficacy of stabilization splints for the management of patients with masticatory muscle pain: a qualitative systematic review. Clin Oral Investig. 2004 Dec;8(4):179-95.

11. Fricton J, Look JO, Wright E, Alencar FGP, Chen H, Lang M, Ouyang W, Velly AM, et al. Systematic review and meta-analysis of randomized controlled trials evaluating intraoral orthopedic appliances for temporomandibular disorders. J Orofac Pain. 2010 Summer;24(3):237-54.

12. Michelotti A, lodice G, Vollaro S, Steenks MH, Farella M. Evaluation of the short- term effectiveness of education versus an occlusal splint for the treatment of myofascial pain of the jaw muscles. Am Dent Assoc. 2012 Jan;143(1):47-53.

13. Schiffman E, Ohrbach R, Truelove E, Look J, Anderson G, Goulet JP, et al. Diagnostic Criteria for Temporomandibular Disorders (DC/TMD) for Clinical Research Applications: Recommendations of the International RDC/TMD Consortium Network and Orofacial pain Special Interest Group. J Oral Facial Pain Headache. 2014 Winter;28(1):6-27.

14. Emshoff R, Emshoff I, Bertram S. Estimation of clinically important change for visual analog scales measuring chronic temporomandibular disorder pain. J Orofac Pain. 2010 Summer;24(3):262-9.
15. Hudek-Knežević J, Kardum I, Lesić R. Efekti percipiranog stresa i stilova suočavanja na tjelesne simptome. Društvena istraživanja. $1999 ; 8,543-561$

16. Barros V de M, Seraidarian PI, Côrtes MI, de Paula LV. The impact of orofacial pain on the quality of life of patients with temporomandibular disorder. J Orofac Pain. 2009 Winter;23(1):28-37.

17. Rener-Sitar K, Petričević N, Čelebić A, Marion L. Psychometric properties of Croatian and Slovenian short form of oral health impact profile questionnaires. Croat Med J. 2008 Aug;49(4):536-44.

18. Von Korff M, Ormel J, Keefe FJ, Dworkin SF. Grading the severity of chronic pain. Pain 1992;50:133-49.

19. Ohrbach R, Larsson P, List T. The jaw functional limitation scale: development, reliability, and validity of 8-item and 20-item versions. J Orofac Pain. 2008 Summer;22(3):219-30.

20. Truelove E, Huggins KH, Mancl L, Dworkin SF. The efficacy of traditional, low-cost and nonsplint therapies for temporomandibular disorder: a randomized controlled trial. J Am Dent Assoc. 2006 Aug;137(8):1099-107; quiz 1169.

21. Alencar F Jr, Becker A. Evaluation of different occlusal splints and counselling in the management of myofascial pain dysfunction. J Oral Rehabil. 2009 Feb;36(2):79-85.

22. Solberg W. Clark G. Rug. Nocturnal electromyographic evaluation of bruxism patients undergoing short-term splint therapy. J Oral Rehabil. 1975 Jul;2(3):215-23.

23. Manns A, Miralles R, Cumsille F.J Prosthet Dent. Influence of vertical dimension on masseter muscle electromyographic activity in patients with mandibular dysfunction. J Prosthet Dent. 1985 Feb;53(2):243-7.

24. Alajbeg IZ, Gikić M, Valentić-Peruzović M. Mandibular Range of Movement and Pain Intensity in Patients with Anterior Disc Displacement without Reduction. Acta Stomatol Croat. 2015;49(2):119-127.

25. MeSH Browser [database on the Internet]. Badel T, Alajbeg I, Marotti M, Kocijan Lovko S. Temporomandibular Joint Disorder Therapy by Occlusal Splint: A Case Report. Acta stomatologica Croatica [updated 22.08.2019.] Available from: https://hrcak.srce. $\mathrm{hr} / 26734$

26. Kirk WS Jr. Magnetic resonance imaging and tomographic evaluation of occlusal appliance treatment for advanced internal derangement of the temporomandibular joint. J Oral Maxillofac Surg. 1991 Jan;49(1):9-12.

27. Augusto VG, Perina KCB, Penha DSG, Dos Santos DCA, Oliveira VAS. Temporomandibular dysfunction, stress and common mental disorder in university students. Acta Ortop Bras. 2016;24(6):330-333. doi:10.1590/1413-785220162406162873

28. Ekberg E, Nilner M. Treatment outcome of appliance therapy in temporomandibular disorder patients with myofascial pain after 6 and 12 months. Acta Odontol Scand. 2004 Dec;62(6):343-9.

29. Alajbeg IZ, Boric Brakus R, Brakus I. Comparison of amitriptyline with stabilization splint and placebo in chronic TMD patients: a pilot study. Acta Stomatol Croat. 2018 Jun;52(2):114-122. 